\title{
The Need to Develop the Established Theory of Partner Violence Further
}

We started this book by showing that, in line with recent research, we would use Johnson's typology of violence in intimate relationships; that is, the divide between intimate terrorism and situational violence. We find that the violence perpetrated against the men we have interviewed must in the main be characterised as intimate terrorism. This is by no means surprising. Johnson points out that situational violence is largely revealed through population surveys, while intimate terrorism is identified through qualitative studies of particular groups exposed to violence. The reason for this is the significant difference between the extent of situational violence and intimacy terrorism detected through prevalence studies. As we have seen in the review of Nordic surveys in Chap. 2, the gender differences seem relatively small in the case of milder forms of physical partner violence, and several studies show that both men and women are both frequently subjected to control and abuse in partner relationships. We want to focus now, therefore, on intimate terrorism, and only to touch on situational violence.

A central premise for Johnson's concept of intimate terrorism is, as mentioned earlier, an asymmetric power relationship. In all relationships where there is serious and systematic violence, there will be a dominant 
party. Feminist-oriented scholars have had a vast influence over the research about family violence and have contributed to highlighting women's and children's experiences of serious violence in intimate relationships. Johnson's theoretical perspective on gender and power has had a major impact on the analysis of clinical trials of abused women. Implicit to Johnson's perspective on intimate terrorism is his theory on gender power, which has its basis in the idea that men as a group dominate women as a group, and that systematic physical violence and control are motivated by the desire for dominance and oppression (Johnson 2008). Over the last decade there has been a cultural shift that has led research communities to recognise that men can be subjected to serious and systematic violence from both women and other men.

One reason for disagreement among partner violence researchers is the lack of clarity about what actually constitutes intimate terrorism. If one emphasises the aspect of control, as Johnson does, then any little slap or push could be considered intimate terrorism, as long as we find that the woman exercises control in a relationship. In that case, the number of male and female perpetrators will necessarily be equal. If the emphasis is placed on more systematic and long-term threatening behaviour and serious violence, which may include psychological, physical and sexual violence, the number of victims of violence will be fewer and we will approach what we might more intuitively understand by the term intimate terrorism.

An understanding of partner violence as a phenomenon which was originally based on the experiences of abused women with violent men, and founded on the understanding of a patriarchal society, must now be developed further to throw light on the serious and systematic psychological and physical partner violence perpetrated against men (see also Bell and Naugle 2008), since partner violence can be committed by both men and women (Simmons et al. 2014). Intimate terrorism can be exercised without the partner having physical superiority.

We find men who are in a privileged economic position and who are physically superior, who are nonetheless exposed to serious acts of violence. These events lead to feelings of worthlessness and suicidal ideation in these men. As shown in Chaps. 4 and 5, in such relationships it is not the partner who is physically superior (the man) who dominates, but the 
woman who exercises psychological control over the man. This book's primary contribution to the international debate on violence in intimate relationships lies perhaps in the fact that we have been able to clearly document the impact of psychological violence against men-what it comprises and how it is experienced. This must also have an impact on our wider understanding of what intimate terrorism entails.

Our research also shows a marked trend that those women who perpetrate violence often have psychological problems and have been both victims and perpetrators. There are strong indications that these women are in need of therapeutic treatment. As mentioned previously, studies of male perpetrators of violence in intimate relationships have shown that six out of ten men undergoing therapy have experienced childhood violence themselves and have major problems with anxiety, depression and substance abuse (Rangul Askeland et al. 2011). In a Norwegian interview study of mothers who inflicted violence on their children, Kruse and Bergman (2014) found that the mothers themselves had had earlier experiences of violence and had also subjected a partner or ex-partner to violence. These women say that the violence often occurred when they found the demands of looking after the children overwhelming. This reflects findings in the international literature on maternal violence (see Kruse and Bergman 2014) and challenges Johnson's (2008) sociological perspective on partner violence, showing the need to supplement it with other theoretical perspectives (see also Bell and Naugle 2008).

In several prevalence studies, Johnson's theory of men's need for dominance over women is used to explain why women are more vulnerable to domestic violence (Dobash and Dobash 1995, 2004; Kimmel 2002). We find it problematic to take the motive behind the violence for granted. Since we have not interviewed the wives and girlfriends (perpetrators) of the men in our survey, we can say nothing about their desire or need to control these men. Future studies should make it a priority to investigate women's motives for exercising violence in the family and to shed light on their experiences. What we can say here is that the men's experiences of being isolated and exposed to this form of violence over long periods erode their self-esteem, their desire to live and their sense of worth.

The psychological violence to which men are subjected, in the form of degradation as fathers, ridicule and humiliation, is not measured in 
several of the major investigations into violence. The most recent and most important survey in Norway investigating violence in intimate relationships does not include any questions about psychological violence (Thoresen and Hjemdal 2014). This necessarily means that the study fails to offer an adequate picture of the extent of violence against men in intimate relationships.

Both family protection and the crisis centre movement in Norway have been dominated by a biased focus on men's violence against women, which has in part been supported by previous feminist studies and the focus of Johnson and other feminist researchers on men's violence. There is reason to assume that a gender bias in samples and in empirical foundations has hindered the furtherance of knowledge about men's vulnerability and need for help (Douglas and Hines 2011; Fjell 2013; Schei and Bakketeig 2007; Grøvdal and Jonassen 2015).

Our study shows that men are also subjected to systematic violence. We find that male victims need help, but that there is significant resistance which makes it difficult for them to seek and access it. This resistance lies within the men themselves, in the relevant organisations and in society, and clearly has its roots in the established discourse about perpetrators and victims of violence. Additionally, much of our theoretical understanding of violence in intimate relationships supports a one-sided focus on women as the vulnerable party. It is crucial that theories be reassessed if we are to extend our knowledge about, and change our attitudes to, violence against men.

\section{Masculinities Studies of Male Violence}

In traditional research into men, the focus has been on men as the perpetrators of violence, and substantially less on them as victims of violence (Connell 1987, 2005; Kimmel 2002, 2006). When, in the late 1980s and early 1990s, men's studies began to establish itself as an independent field, it was strongly influenced by the contemporaneous feminist criticism of patriarchal structures. Historically, women as a group had been oppressed by men, economically, socially and ideologically. When it came to the question of violence, it was presented as a fact that men were the 
instigators of most violence, both at a collective and social level as well as on an individual level. It is the violence on an individual level that impacts many women and children. Men's violence towards, and general suppression of, women was the dominant social pattern in most societies; a gender-based suppression was in existence. This meant that the question of power became central, even in the emerging feminist-inspired research into men. This was further reinforced by the fact that this research was often fused with Marxist criticism of the capitalist society. Here, gender relations were understood in the same way that Marxism understood the relationship between the social classes: just as the bourgeoisie in a capitalist society was seen to be oppressive and to possess greater resources than the working classes, so too was the relationship between men and women seen as one of oppressor and oppressed. This thinking is apparent in sociologist R. W. Connell's theory of dominant hegemonic masculinity, which remains the most influential theory in this field.

Connell $(1987,2005)$ challenges the tendency in early feminist research to observe and describe men as one unique and homogeneous group. Connell points out that there are significant variations between men's circumstances and attitudes, which require us to talk about masculinities in the plural (Connell 2005). There are, for example, groups of oppressed men whose access to economic and political resources is more restricted than that of more influential men. Other groups of men are marginalised and largely powerless, for instance because of their ethnicity or other reasons. However, Connell only sees this oppression or marginalisation in relation to other men-these men are never seen as oppressed or marginalised in relation to women (Connell 2005).

Despite the fact that Connell demonstrates that there are various types of masculinities in any given society, with varying access to power, influence and resources, he upholds the original feminist premise that men as a group are always oppressive to women. Certain men can of course oppress other men, make them victims of violence, exploit them economically or marginalise them, yet these male victims nonetheless occupy a superior position to women (Connell 2005). The inner logic of this theory makes it virtually impossible to see women as anything but subordinate to men, and as victims of men's power and violence. 
Although Connell's relatively influential theory is largely used within the field of social science, the same logic has also influenced major sections of men's studies, including historical research on men (Rotundo 1993; Kimmel 2002, 2006; Tjeder 2003). Despite various attempts at offering greater nuance, the feminist gender-power perspective on male dominance and female subordination prevails.

\section{The Need for Alternative Theoretical Perspectives}

As Jennifer Lawson (2012) points out, we must now work to bridge gaps between the polarised theories of violence and gender. The field of research on violence is still largely shaped by a sociological gender-power perspective and an oppressed/oppressor model. Not only is this problematic in the understanding of women, it is also highly problematic in the understanding of men. Nor does the gender-power model make sense in the analysis of violence in gay relationships.

From a historical perspective, it easy to understand why theoretical analyses have emphasised men's power. This is also understandable from a global perspective. The problem is that it has closed the way for a more phenomenological and realistic understanding of violence in intimate relationships, where both men and women are perpetrators of violence and power. There is not just one truth about serious partner violence and there cannot therefore be one theory to explain it: neither the causes of violence nor the reasons why some people are exposed to serious and systematic violence in intimate relationships. There is good reason to question physical superiority as a "natural" explanation of systematic partner violence, and of the fear of (more) violence. An uncritical acceptance of the discourse about the female victim and the myth of the good mother can contribute to acceptance of the violence perpetrated by women and mothers in intimate relationships, but also to the concealment of the violence that exists in gay relationships.

Established narratives of partner violence set limits on how men can talk about their experiences of violence. Foucault describes how discourses create "truth effects" (Foucault 1977). As we saw in the chapter 
on partner violence (Chap. 5), fathers feel that they must avoid bringing up the subject of women's violence in any discussion relating to children and their care, because they are afraid they might be suspected themselves. The accepted thinking within family protection appears to be characterised by the belief that the mother is best for the child and that men are perpetrators of partner violence, not the victims of it.

In Scandinavian men's studies, there has been a desire to show that many men in this part of the world have been positive in their attitude to more egalitarian relationships between the sexes; and that they have distanced themselves from the negative traits traditionally attached to the notion of manliness, such as violence or unwillingness to take responsibility for children and family (Holter 2007; Aarseth 2011). Using the concepts of unmanliness/manliness, some scholars have attempted to demonstrate the wide variations that characterise different forms of masculinity, where forms of manliness are almost always created and defined in direct relation to forms of unmanliness — which are marginalised and repudiated (Liliequist 1999; Andersson 2004; Lorentzen 2004; Ekenstam 2006; Lorentzen and Ekenstam 2006). Unmanliness, just like manliness, is dependent on historical context. At times unmanliness has been linked with a derisive view of femininity (Connell 1987; Kimmel 2002), but by no means always.

With this theoretical approach it has been possible to get closer to a more real and complex picture of manliness in all its diversity. This is a picture that shows vast differences in access to power and status among men, and recognises that many men are, or have been, subjected to oppression in similar ways to women. There was a desire to make clear the sense of emotional loss and powerlessness that exists in many ordinary men's lives. In several of the studies that look at the play between manliness and unmanliness, a need has been identified for a more phenomenological perspective; that is, we must listen to men's own voices and take their personal experiences seriously (Lorentzen 2004; Ekenstam 2006; Lorentzen and Ekenstam 2006).

Although we see that these attempts offer a more phenomenological picture of men's actual experiences, and of the variety and complexity that exist, we find, based on our present study, that this perspective has also been limited. Firstly, it seems from many of our interviews that some 
men who occupy the position of victim do not perceive themselves as unmanly, but on the contrary as manly. Secondly, it seems that it is not only other men, as previously believed, who define men as unmanly, but also the women with whom they have relationships. There is also the question of how important the matter of womanliness/manliness/unmanliness actually is to men's self-image, or, indeed, to our analysis of their relationships.

\section{Some Problems with Structuralist Theory}

A prominent voice in men's studies which has long criticised the biased focus on structural power relationships and the lack of a phenomenological perspective is that of sociologist Victor Seidler (1994, 1997, 2004). Seidler maintains that one problem with a structuralist theory is its universalism: it is a rationalist theory with generalisable claims. The variables are given beforehand, which means that many of the more selfcontradictory features of reality are squeezed into overly narrow conceptual frameworks. In line with a western (generally masculine) scientific tradition, it reduces cultural variations, personal experiences and feelings to a minimum. Feelings such as grief, fear and vulnerability are acknowledged as little in this research as they are within the dominant male culture. This biased focus on structural relationships is even accompanied by the dismissal of what we can call the "personal", "emotional" or "therapeutic", particularly here, where power is presented as the most relevant question. Although there is a significant link between the concepts of manliness and power (and violence), manliness cannot always be reduced to power. As Ekenstam (2006) argues, the diversity of male identities, as well as the relationships between men and women, is too complex and the contradictions too many.

Seidler points out that an understanding of the power relationship between the genders, and the various social structures, must be the starting point of our analysis, not the end point. The biased structuralist approach to research on masculinity has meant that we actually know very little about how men think or perceive themselves. The neglect, abuse and violence they have experienced as children, as well as the dis- 
empowerment they may also have experienced, tend to be rendered invisible when masculinities are only seen in terms of power relationships. We lack insight into the fear, pain, suffering and sense of insecurity that many boys and men (also) experience throughout their lives.

Seidler believes it is necessary to develop new methods for interviewing men about their personal relationships. The researcher must be prepared to build a personal relationship and to allow men's own voices to be heard. It was just such an approach that inspired our work with this book.

In our study we have wanted to let the men tell their own stories and to allow their voices to come through. This study shows a complex picture of the violence to which men are subjected. Violence can be systematic over a period of time, it is psychological and physical, and it is threatening and dangerous. According to accounts given by the men who are experiencing partner violence, female perpetrators often (strategically) use society's assumption that men are assumed to be the violent partner. The challenge has been to meet these male voices with a theoretical understanding of the relationship between gender and family dynamics, and the relationship between each individual's history and their present situation.

In our interviews we talked to men about feelings of unmanliness associated with being exposed to violence, based on theories of unmanliness. We found, however, that men rarely define themselves as or see themselves as unmanly because they are victims of violence, or because they do not retaliate. On the contrary, many of them emphasise that they see it as an expression of manliness when they do not hit back. Additionally, both those who have/had male or female partners express that they had no intention or desire to use violence against their partner. This differs from the findings of several other interview studies, which have found that male victims of partner violence perceive themselves as unmanly (Bjerkeseth 2010; Morgan and Wells 2016).

Seidler (1994, 1997) criticizes structural perspectives that take their starting point in (male) physical and economic supremacy. Our study shows that men who are subjected to violence can in fact be socially and/ or economically dominant, and that they see their strategy of nonviolence as an expression of manliness. When, despite these factors, men 
are subjected to systematic violence, it seems obvious that a structural perspective is inadequate in seeking to understand violence towards men.

We need to include the dimension of psychological dominance if we are to explain psychological/physical violence against men. A position of psychological dominance is as easy for a woman to occupy as it is a man, and thus the analysis of violence will not be so strongly linked to the man. Such a theory will mean that gender itself will become less relevant to the understanding of violence in intimate relationships (see McHugh et al. 2013).

Our interviews show that these men have felt enormous caring and empathy for their partners. Despite being subjected to systematic and serious violence, they try to understand their violent partners and are concerned for the partners' care needs. These men find coping strategies in order to live with the violence, and for many of them this involves trivialising or under-communicating it. Meanwhile, some do not perceive themselves as being the victims of violence before a substantial amount of time has passed. One reason for this may be that men, like society and institutions in general, have internalised the understanding that women, not men, are exposed to violence. Thus, they lack the concepts for the violence to which they are exposed, until the violence has escalated to the point that it represents a real threat.

We suggest that new theoretical understandings of violence are urgently needed. Such a theorising must take into account the findings in this study. That is to say, it must be acknowledged that men also experience intimate terrorism in close relationships. One can no longer claim, as Johnson has done a number of times, that intimate terrorism is "almost exclusively" perpetrated by men. We have no basis on which to discuss the extent of violence towards men in comparison to the same form of violence towards women. Nor, perhaps, is this the most important factor in developing theoretical perspectives further. We need to adapt our research in order to get a better picture of the extent and nature of the intimate terrorism directed at men. A theoretical understanding that includes men who are exposed to serious violence necessarily implies that the traditional gender-power discourse must be modified and supplemented (see Bell and Naugle 2008). Violence in intimate relationships is 
a complex phenomenon that requires a variety of theoretical approaches (Bell and Naugle 2008; Lawson 2012). Perspectives and theoretical models must acknowledge that violence is perpetrated in same-sex relationships and by both sexes in heterosexual relationships; that ethnic background/nationality/residence status can further complicate matters; and finally that both the perpetrator's and the victim's personal histories are of importance. Our empirical findings also indicate that violence can have a basis in psychological dominance, and is therefore less linked to womanliness or manliness than previously thought. As we have touched upon, social backgrounds are relevant too in our understanding of people's vulnerability in a partner relationship.

\section{Future Research on Violence in Intimate Relationships}

Our study shows that there is a need for a more nuanced understanding of power relationships with regard to family violence, sexual abuse and intimate terrorism. It is not enough to investigate physical/economic superiority (structural power relationships) in order to understand violence in intimate relationships. As Russel Dobash and Emerson Dobash (2004) have pointed out, further research on violence in intimate relationships must include in-depth research about women's violence to male partners. We find that the structuralist understanding of violence must be supplemented with an understanding of how psychological dominance can provide a basis for power and coercion. As already outlined, it is necessary to have a new theoretical understanding of violence in intimate relationships which includes violence against men. Such an understanding implies that Johnson's concept of intimate terrorism also includes women's violence against men. Kimmel (2002) has suggested methods to reconcile the disparate data of gender symmetry and gender asymmetry, and encourages researchers and practitioners to acknowledge women's use of violence, while simultaneously understanding why this violence tends to be different from that perpetrated by men towards their female partners. 
Our proposals for future research on violence in intimate relationships are as follows:

- Several larger qualitative studies of boys' and men's experiences and of how violence and sexual abuse in intimate relationships are handled.

- Closer investigation of the mechanisms behind men's silence on the subject of violence and abuse.

- Inclusion of gender and class perspectives in future studies.

- Method-development projects with the aim of improving the quality of research into violence against boys and men.

- Further studies that map the requirements of men for help and support.

- Future prevalence studies including questions that can throw light on various forms of psychological violence among adults.

\section{References}

Aarseth, H. (2011). Moderne familieliv: Den likestilte familiens motivasjonsformer (Modern Family Life: Forms of Motivation in the Equality Based Family). Oslo: Cappelen Damm akademisk.

Andersson, S. (2004). Maktrelationer mellan män genom ålder. Status, auktoritet och marginalitet inom närpolisen (Power Relations Between Men Throughout Life. Status, Authority and Marginality in Local Policing. Kvinnnovetenskaplig tidskrift, nr 1-2. Retrieved from http://130.241.16.45/ ojs/index.php/tgv/article/viewFile/2304/2058.

Bell, K. M., \& Naugle, A. E. (2008). Intimate Partner Violence Theoretical Considerations: Moving Towards a Contextual Framework. Clinical Psychology Review, 28(7), 1096-1107.

Bjerkeseth, L. B. (2010). Den Mannlige Offerrollen: En Intervjustudie Av Menn Som Opplever Vold Fra Kvinnelig Partner (The Male Victim: An Interview Study of Men Who Experience Violence by Female Partners). Master's dissertation, Department of Sociology and Social Geography at the University of Oslo. Retrieved from https://www.duo.uio.no/handle/10852/15305.

Connell, R. (1987). Gender and Power: Society, the Person and Sexual Politics. Cambridge: Polity Press. 
Connell, R. (2005). Masculinities (2nd ed.). Berkley: University of California Press.

Dobash, R. P., \& Dobash, R. E. (1995). Reflections on Findings from the Violence Against Women Survey. Canadian Journal of Criminology, 37(3), 457-304.

Dobash, R. P., \& Dobash, R. E. (2004). Women's Violence to Men in Intimate Relationships: Working on a Puzzle. British Journal of Criminology, 44(3), 324-349.

Douglas, E., \& Hines, D. (2011). The Helpseeking Experiences of Men Who Sustain Intimate Partner Violence: An Overlooked Population and Implications for Practice. Journal of Family Violence, 26(6), 473-485.

Ekenstam, C. (2006). The History and Future of Studies on Men and Masculinity: Some Theoretical Reflections. Norma: Nordisk Tidsskrift for Maskulinitetsstudier (Nordic Journal for Masculinity Studies), 1(1), 6.

Fjell, T. (2013). Den usynliggjorte volden: Om menn som utsettes for partnervold fra kvinner (The Invisible Violence: About Men Subjected to Partner Violence from Women). Trondheim: Akademika.

Foucault, M. (1977). Discipline and Punish: The Birth of the Prison. New York: Pantheon Books.

Grøvdal, Y., Jonassen, W., \& Nasjonalt kunnskapssenter om vold og traumatisk stress (The Norwegian Centre for Violence and Traumatic Stress Studies). (2015). Menn på krisesenter (Men at Crisis Centres) (Vol. 5/2015, Report (Nasjonalt kunnskapssenter om vold og traumatisk stress: trykt utg.)) (The Norwegian Centre for Violence and Traumatic Stress Studies). Oslo: Nasjonalt kunnskapssenter om vold og traumatisk stress (The Norwegian Centre for Violence and Traumatic Stress Studies). Retrieved from https:// www.nkvts.no/rapport/menn-pa-krisesenter/.

Holter, Ø. (2007). Män i rörelse: Jämställdhet, förändring och social innovation $i$ Norden (Men in Motion: Gender Equality, Change and Social Innovation in the Nordic Region). Stockholm: Gidlund.

Johnson, M. P. (2008). A Typology of Domestic Violence. Boston: Northeastern University Press.

Kimmel, M. (2002). "Gender Symmetry" in Domestic Violence. Violence Against Women, 8(11), 1332-1363.

Kimmel, M. (2006). Manhood in America: A Cultural History (2nd ed.). New York: Oxford University Press.

Kruse, A., \& Bergman, S. (2014). "Jeg kan jo ikke kalle det noe annet enn vold-": En forskningsoversikt og en intervjustudie om modres vold mot barn ("I Can't 
Call It Anything Else Than Violence": A Research Review and Interview Study of Mothers' Violence Against Children) (Vol. 4/2014, Report) Nasjonalt kunnskapssenter om vold og traumatisk stress (The Norwegian Centre for Violence and Traumatic Stress Studies). Oslo: Nasjonalt kunnskapssenter om vold og traumatisk stress. Retrieved from https://www.nkvts.no/rapport/jeg-kanjo-ikke-kalle-det-noe-annet-enn-vold-en-forskningsoversikt-og-enintervjustudie-om-modres-vold-mot-barn/.

Lawson, J. (2012). Sociological Theories of Intimate Partner Violence. Journal of Human Behavior in the Social Environment, 22(5), 572-590.

Liliequist, J. (1999). Från niding till sprätt. En studie i det svenska omanlighetsbegreppets historia från Vikingatid till sent 1700-tal (From Caitiff to Weakling: A Study of the Concept of Unmanliness from Viking Times to the 18th Century) In A-M Berggren Manligt och omanligt i ett historiskt perspektiv (Manliness and Unmanliness in a Historical Perspective). Stockholm, Forskningsrådsnämnden (Research Council), Report 99:4.

Lorentzen, J. (2004). Maskulinitet: Blikk på mannen gjennom litteratur og film (Masculinity: Looking at Man Through Literature and Film). Oslo: Spartacus. Lorentzen, J., \& Ekenstam, C. (2006). Män i Norden: Manlighet och modernitet 1840-1940 (Man in the Nordic Regions: Manliness and Modernity). Hedemora: Gidlund.

McHugh, M., Rakowski, C., \& Swiderski, S. (2013). Men’s Experience of Psychological Abuse: Conceptualization and Measurement Issues. Sex Roles, 69(3), 168-181.

Morgan, W., \& Wells, M. (2016). 'It's Deemed Unmanly': Men's Experiences of Intimate Partner Violence (IPV). The Journal of Forensic Psychiatry \& Psychology, 27(3), 1-15.

Rangul Askeland, I., Evang, A., \& Heir, T. (2011). Association of Violence Against Partner and Former Victim Experiences: A Sample of Clients Voluntarily Attending Therapy. Journal of Interpersonal Violence, 26(6), 1095-1110.

Rotundo, E. (1993). American Manhood: Transformations in Masculinity from the Revolution to the Modern Era. New York: Basic.

Schei, B., \& Bakketeig, L. S. (2007). Kvinner lider-menn dør: Folkehelse $i$ et kjønnsperspektiv (Women Suffer-Men Die: Public Health in a Gender Perspective). Oslo: Gyldendal akademisk.

Seidler, V. (1994). Unreasonable Men: Masculinity and Social Theory (Male Orders). London: Routledge.

Seidler, V. (1997). Man Enough: Embodying Masculinities. London: Sage. 
Seidler, V. J. (2004). Des/orienterade maskuliniteter. Kroppar, känslor och rädsla (Dis/orientated Masculinities. Bodies, Feelings and Fears. Kvinnnovetenskaplig tidskrift $\mathrm{nr} 1-2$.

Simmons, J., Wijma, B., \& Swahnberg, K. (2014). Associations and Experiences Observed for Family and Nonfamily Forms of Violent Behavior in Different Relational Contexts Among Swedish Men and Women. Violence and Victims, 29(1), 152-170.

Thoresen, S., \& Hjemdal, O. K. (2014). Vold og voldtekt i Norge: En nasjonal forekomststudie av vold $i$ et livslopsperspektiv (Violence and Rape in Norway: A National Prevalence Study of Violence in a Lifespan Perspective) (Vol. 1/2014, Report (Nasjonalt kunnskapssenter om vold og traumatisk stress: trykt utg.)) (The Norwegian Centre for Violence and Traumatic Stress Studies). Oslo: Nasjonalt kunnskapssenter om vold og traumatisk stress (The Norwegian Centre for Violence and Traumatic Stress Studies). Retrieved from https:// www.nkvts.no/rapport/vold-og-voldtekt-i-norge-en-nasjonal-forekomststudie-av-vold-i-et-livslopsperspektiv/.

Tjeder, D. (2003). The Power ofCharacter. Middle-Class Masculinities, 1800-1900. Stockholm: Doctoral Thesis Monograph-University of Stockholm.

Open Access This chapter is licensed under the terms of the Creative Commons Attribution 4.0 International License (http://creativecommons.org/licenses/ by/4.0/), which permits use, sharing, adaptation, distribution and reproduction in any medium or format, as long as you give appropriate credit to the original author(s) and the source, provide a link to the Creative Commons licence and indicate if changes were made.

The images or other third party material in this chapter are included in the chapter's Creative Commons licence, unless indicated otherwise in a credit line to the material. If material is not included in the chapter's Creative Commons licence and your intended use is not permitted by statutory regulation or exceeds the permitted use, you will need to obtain permission directly from the copyright holder.

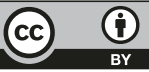

